\title{
DEN TAKSONOMISKE TAKTSTOK
}

\author{
STIG TOFT MADSEN
}

Denne artikel handler om, hvordan fugleinteresserede i Danmark og Sverige finder og bestemmer fugle, og hvordan fund af sjældne arter valideres eller falsificeres $i$ en kontekst præget af teknologiske og videnskabelige landvindinger. Både den erfarne observatør og nybegynderen har brug for en model til at artsbestemme og indplacere den fugl, som han eller hun har fundet. Denne model leveres af taksonomer. Ligesom amatørornitologer er taksonomer drevet af behovet for at skabe orden og stabilitet. Carl von Linné søgte naturens orden, som for ham var Guds evige orden. Hvis han ikke fandt den, var han villig til opfinde den (Lindroth 1988:24). Linné var botanikkens lovgiver; en skolastiker, som førte taksonomiens taktstok med stor gennemslagskraft. Tilsvarende stræber nutidens taksonomer efter løbende at forbedre deres model ud fra deres viden om livet på jorden som en evolutionær proces. De udarbejder imidlertid ikke denne model af livets træ eller ,livets mangrove“" eller ,livets ring“ (Hodkinson \& Parnell 2019:11) for at glæde amatørornitologerne. Forholdet mellem taksonomer og feltornitologer er ikke egalitært. Taksonomien skaber det univers, inden for hvilket feltornitologien udfolder sig. Selv erfarne feltornitologer må acceptere eksistensen af den taksonomiske taktstok, men det betyder ikke nødvendigvis, at de er uden egen stemme. Dygtige feltornitologer er snarere menige med officersrang - ,subalterns“ $i$ ordets oprindelige betydning. Ikke mindst denne dobbeltrolle gør feltornitologien til en relevant genstand for videnskabsfilosofisk og samfundsvidenskabelig analyse.

Således jonglerede Thomas S. Kuhn i en artikel fra 1974 med et tænkt eksempel hentet fra feltornitologien til forståelse af, hvordan et kognitivt apparat tillæres. Kuhn beskrev, hvordan en far på en tur i en zoologisk have lærer sin søn at se forskel på gæs, ænder og svaner ved at koncentrere sig om simple silhuetter. Med en fornemmelse for svaners distinkte silhuet og en viden om, at voksne svaner er hvide, vil en eventuel fremtidig sort svane skille sig ud. Ny information vil have konsekvenser, men det kognitive apparat vil kunne tillem- 
pes (Kuhn 1977:312). To af Kuhns prominente arvtagere, John Law og Michael Lynch, bruger på samme måde feltornitologien som afsæt til at forstå, hvordan videnskab etableres. Deres genstandsfelt er en analyse af de felthåndbøger, som siden 1930'erne gennem pædagogiske illustrationer og fotos, kort og tekster på trods af deres begrænsninger (benævnt „troubles“) har gjort novicer til habile fuglekendere (Law \& Lynch 1990). Nogle amatørornitologer går videre og agerer som eksperter i professionelle sammenhænge. Som natur- og kulturhistorikeren Jeremy Mynott vælger at formulere det med evolutionsbiologen Ernst Mayrs ord fra 1962:

Der er næppe nogen anden gren inden for biologien, eller inden for videnskab som sådan, hvortil amatøren har bidraget så meget som ornitologien. Jeg finder egentlig ordet 'amatør' upræcist, fordi det signalerer en dilettant, og det ville være en misvisende beskrivelse af mange førende ornitologers arbejde (Mynott 2009: 19 , min oversættelse).

En sådan ekspertise tangerer hermed, hvad videnskabssociologen Harry Collins kalder „contributory expertise“ - viden som rykker grænser (Collins 2013). Feltornitologien er med andre ord demokratisk og inklusiv i den forstand, at den som fritidsbeskæftigelse er åben for alle interesserede, men samtidig er den et felt, hvor eksperter krydser klinger, i takt med at ornitologien udvikler sig fra det stadie, som Law og Lynch iagttog. Nærværende artikel kredser om disse amatører, der dyrker deres interesse som en seriøs hobby på linje med en videnskab. ${ }^{1}$ I artiklen vil jeg først gennemgå artsbegrebets udvikling inden for ornitologien for derefter at vende mig mod feltfolkets livtag med identifikation af sjældne fugle. Mine data er primært fra efteråret 2019, hvor jeg selv var ganske aktiv på forskellige lokaliteter i Danmark og Sverige, og hvor jeg sideløbende med at se på fugle gjorde notater med henblik på denne artikel. Jeg vil inddrage læseren gennem virkelighedsnære beskrivelser af en række „events“ for at anskueliggøre, hvordan det at lokalisere sjældne arter finder sted i en blanding af videnskab og sport, samarbejde og konkurrence. At se på fugle er blevet beskrevet som „den mest videnskabelige af sportsgrene eller den mest sportslignende af videnskaber" (Kastner 1986:4-5) - en mobilisering af både homo sapiens og homo ludens. I dette spil om at se sjældne fugle forsøger den enkelte sportsudøver på egen hånd at finde og identificere, og dermed i intern jargon at ,ædle“, sjældne fugle, men andre personer og nye teknologiske hjælpemidler inddrages stadig oftere i bestemmelsesprocessen. Årligt udgives i omegnen af 20.000 videnskabelige publikationer med relation til fugle (Birkhead et al. 2014:viii). Som helhed er litteraturen om fugle og om fuglefolk ikke blot omfangsrig, men især på engelsk af høj faglig og litterær kvalitet. ${ }^{2}$ Den nordiske litteratur er ofte af tilsvarende kaliber. 
I etnologisk og antropologisk sammenhæng findes en håndfuld nyere nordiske studier, inklusive Liep (1996, 2001), Samuelson (2006), Hundeide (2013), Lundquist (2018) og Skog (2018). Min opfattelse af feltet adskiller sig ikke afgørende fra deres. Jeg er enig med John Liep i, at den enkelte artsjæger kan siges at tilstræbe „kumulativ besiddelse“, samtidig med at han eller hun typisk deler „byttet" eller gaven med de øvrige tilstedeværende, de tilrejsende ligesindede samt fagornitologien. Mit fokus er dog mere på den videnskabelige verden, som omgiver feltornitologien, end det var for Liep. Folkemindeforskeren Susanne Nylund Skog fremhæver det særegent mandlige ved fugleinteressen. Dette forhold, som også kendes fra USA (Lee et al. 2015), står utilsløret frem i Per Samuelsons speciale, hvor mænds galskab er i fokus. Dedikerede fuglefolk omtaler ofte sig selv og deres ligesindede som galninge. Mit fokus er ikke på, hvordan galskab skaber fællesskab, men på, hvordan denne sport udfolder sig på et videnskabeligt grundlag. Sammenlignet med Michael Hundeide, som lister antropologiens teoretikere med samme grundighed, som artsjægere lister fugle, er min tilgang teoretisk spartansk. Jeg distancerer mig dog mere markant fra den tilgang, som antropologen Andrew Mitchell præsenterer i sit studie af ulve i Sverige. Mitchell selv har aldrig set en levende vild ulv, men det er irrelevant. Hans ambition er at „spore“ ulven som den „manifesteres“via fodspor, via urin og fækalier i sneen, via byttedyr, via GPS-data, som nedlagt problemulv, gennem obduktion, som museumsgenstand eller via nyhedsstrømmen og ikke mindst gennem DNA-analyse, som er ,the name of the game“" i svensk ulveforvaltning (Mitchell 2018: 40). Hermed forfølger Mitchell de postmodernistiske spor, som John Law og især Annemarie Mol og Karen Barad har afsat. Her opløses levende og dødt i gensidig intra-aktion, ,... der findes som sådan ikke adskilte ting ..." (Mitchell 2018:49). I denne ontoepistemologi er næsten alt „multipelt“. Dér er fuglefolket ikke endnu. Det er korrekt, at feltornitologien ikke har den brede berøringsflade med dyret, som Mitchell beskriver. Feltornitologien er mindre taktil, men som regel ses og høres fuglene godt nok til, at de entydigt kan artsbestemmes uden den obligatoriske „blurring of boundaries“, som postmodernismen foreskriver (Pluckrose \& Lindsay 2020:31). Jeg italesætter et univers, som er foranderligt, men forbliver artscentreret, på trods af at den feltornitologiske praksis og faglighed udfordres af udviklingen inden for kunstig intelligens og molekylærbiologi og af den postmodernisme, som Mitchell er inspireret af. I pagt med at mange feltornitologer bidrager til viden gennem impromptuseminarer i felten, på diverse hjemmesider og i form af egentlige publikationer, vil de i teksten fremstå under eget navn. Dansk feltornitologi præsenteres ofte som en rivalisering mellem to personer: den joviale Jørgen Munck og udfordreren Rolf Christensen. Jeg ønsker i stedet at fremstille den hårde kerne som et kommunikativt netværk på et 
par hundrede meget dygtige og aktive personer. Antallet af hårde observatører (,hårdskådare") er højere i Sverige, hvor en meget sjælden fugl trækker omkring 500 raritetsentusiaster. Tusindtallige skarer af sådanne ,twitchers“ forekommer ikke i Norden, men kunne opleves på De Britiske Øer, før coronapandemien hæmmede bevægelsesfriheden. ${ }^{3}$

\section{Taksonomiens historie}

I antologien Naturens sprog (Gjerris \& Rubow 2018) italesættes evnen til at lade sig fortrylle af naturen. Morten D.D. Hansens bidrag bærer titlen „Vi, som inhalerede“. Hans artikel er en veritabel ode til det at se på fugle (Hansen 2018). Udgangspunktet for nærværende artikel er mere prosaisk, nemlig arter og taksonomi. At inddele fuglene i arter handler om at klassificere, systematisere og navngive dem med et køligt blik og ikke om at lade sig henføre eller forføre. At opstille en taksonomi er at afkode naturens sprog, men med lidt god vilje kan man også sige, at taksonomien gør det muligt at inhalere skaberværket/biodiversiteten art for art og kryds for kryds. Artsjægere fører typisk detaljerede lister over de arter, som de observerer. Observationerne lægges ofte ud på hjemmesider, hvoraf deres indbyrdes placering fremgår. På den svenske Club300's hjemmeside findes blandt andet en sverigesliste, en liste for hver landsdel, en liste for hver måned, lister for hvert af årene fra 2004 til 2021, lister for forskellige dele af verden, en verdensliste, og en ædelliste. Sidstnævnte registrerer de arter, som observatøren selv har opdaget. Over 2.000 observatører (,skådare") har indtastet deres sverigesliste, som er den vigtigste liste for svenske listeførere eller „kryssare“. Øverst på listen ligger Bertil Svensson med 479 arter.

I Danmark er der to danmarkslister. Den ene føres af netfugl.dk. På denne, hvortil 1.394 personer har bidraget, er Jørgen Munck „toplister“ med 455 danmarksarter. På den alternative club300.dk-liste ligger Mandø-kenderen Tim Hesselballe Hansen øverst med 450 arter. $^{4}$

På både den svenske og de to danske lister er det arter, der tæller. Andre taksonomiske niveauer som underarter, de artsklynger, som botanikere gerne opererer med, eller slægter lader sig ikke afkrydse for nærværende. Der er i udgangspunktet intet til hinder for at oprette ikke-artsfokuserede lister. Feltornitologer interesserer sig ofte for underarter, både fordi det er udfordrende, fordi nogle underarter ender med at få artsstatus og dermed udløser et såkaldt „,sofakryds“, og fordi nogle hidtil ,gode“ arter mister artsstatus. Der er heller intet til hinder for at vægte kryds forskelligt. For eksempel kunne observationer uden brug af privatbiler tælle dobbelt. Sådanne skridt i retning af en mere forbrugerorienteret eller individualiseret taksonomi vil imidlertid øge sandsynligheden for intern 
uenighed $\mathrm{i}$ et felt, som i forvejen ikke er fuldt standardiseret. Taksonomer har typisk et længere tidsmæssigt perspektiv end feltornitologer. Hvor listeførerens hele habitus bygger på, hvad der kan skelnes i felten, giver det fin evolutionsbiologisk mening at påstå, at ,på en måde er alt i taksonomien hypotetisk, selv arterne“" (del Hoyo \& Collar 2014:46, min oversættelse). Det er nemlig et faktum, at alle livsformer på alle taksonomiske niveauer gennemgår cyklusser af ekspansion og kontraktion. På den anden side kan en sådan cyklus tage en million år, så artsbegrebet har en vis soliditet.

Taksonomiens udvikling er beskrevet i den 35 sider lange indledning til Illustrated Checklist of the Birds of the World (del Hoyo \& Collar 2014). Denne tjeklistes tilgang er vokset ud af de erfaringer, som de foregående to årtiers arbejde med Handbook of the Birds of the World (HBW) i 17 bind i stort format havde kastet af sig. Udgangspunktet er det biologiske artsbegreb, der definerer arter som populationer, som reproducerer sig selv over tid. To populationer, som bevarer deres reproduktive isolation selv i områder, hvor deres udbredelse overlapper, betragtes som to biologiske arter. To populationer, som lever geografisk adskilt fra hinanden, men ligner hinanden meget, er et problem for det biologiske artsbegreb. Kan de regnes for samme art, som blot er udbredt allopatrisk i to adskilte områder?

Carl von Linnés systematik indeholdt flere taksonomiske rangordener, hvoraf „art“ var det laveste. I 1909 udgav R.B. Sharpe en liste over verdens fugle baseret på Linnés systematik. Listen indeholdt 18.939 arter. Efterfølgende vandt det trinominale system indpas på bekostning af Linnés binominale nomenklatur. Ved at indføre et taksonomisk lag under artsniveauet reduceredes antallet af arter drastisk. I 1946 blev antallet af fuglearter således anslået til 8.614, idet en række arter var blevet reduceret til underarter eller racer. I 2014 udgav Tim Birkhead et al. en bog om ornitologiens historie med titlen Ten Thousand Birds. Antallet af fuglearter er tydeligvis mere konstant end for eksempel antallet af insektarter, som stiger hastigt, ikke mindst fordi det er biologerne magtpåliggende at beskrive tusindvis af endnu ubeskrevne arter, før de muligvis uddør (Hodkinson \& Parnell 2019). Tilvæksten i antallet af fuglearter i dag skyldes i langt højere grad opsplitning af eksisterende arter end opdagelsen af nye. Opsplitningen kan være baseret på udseende, men det er blevet nemmere også at inddrage sang og kald i bestemmelsen af artstilhørsforhold. Sangen indgår i pardannelsen, men sangen kan variere individuelt. Fuglenes kald, som ofte høres hele året, er formodentlig mere entydigt arveligt bestemt end sangen. Med analyse af sonogrammer kan man derfor nå langt $\mathrm{i}$ at fastlægge arternes indbyrdes forhold.

Det fylogenetiske artsbegreb blev lanceret omkring 1983 i et forsøg på at løse problemerne med det biologiske artsbegreb (del Hoya \& Collar 2014:23-24). 
Her er en art „,en mindst mulige gruppe af individer, der alle deler en unik kombination af karaktertræk og evolutionært kan spores tilbage til den samme forfader" (Lottrup 2020). Det fylogenetiske artsbegreb har utvivlsomt bidraget til væksten i antallet af arter, men derudover påstår del Hoyo og Collar (2014:14) bramfrit - og uden beviser, at artsjægernes interesser bidrager i samme retning. Artsjægerne presser taksonomer til at opsplitte arter, for at de selv kan fă flere kryds! På samme måde er det ofte blevet fremført, at naturbeskyttelsesinteresser tilskynder taksonomer til at definere tvivlsomme arter for nemmere at kunne påtage sig at beskytte dem.

En fjerde spilfornyer i tillæg til det fylogenetiske artsbegreb, artsjægerlobbyen og naturbeskyttelseslobbyen er eksplosionen af genetiske studier. Disse studier har afsløret - ,revealed“ er det ord, som ofte bruges (jf. Zhang et al. 2014) mange nye forhold på artsniveau, men mere dramatisk på de overordnede taksonomiske planer. Revolutionen tog fart på en kongres i Canada i 1986, hvor C.G. Sibley præsenterede fuglenes stamtræ baseret på DNA-studier (Birkhead et al. 2014:108-09). Nu er der enighed om, at falke ikke er rovfugle, som man umiddelbart skulle tro, men derimod nært beslægtet med papegøjer. Den store gruppe af spurvefugle er faktisk også ret nært beslægtet med papegøjer; „,noget, som ingen tidligere har kunnet forestille sig ud fra forskelle i næb og fødder" (Fjeldså 2013:224). På nuværende tidspunkt nærmer vi os en situation, hvor ikke bare de overordnede ordeners, familiers og slægters indbyrdes relation er blevet kortlagt, men hvor alle verdens fuglearter har fået kortlagt hele deres genom. For 20 år siden var man begrænset til at fokusere på ikke-cellekernemitokondrie-DNA, hvor generne nedarves fra moderen. Nu er man i stand til for cirka 1000 dollar per art at kortlægge en arts totale arvemasse, altså hele genomet med flere milliarder DNA-baser (Fjeldså 2015:4; Fjeldså 2020; Maclean et al. 2005). I dette arbejde har Statens Naturhistoriske Museum og Københavns Universitet spillet en vigtig rolle i samarbejde med blandt andre verdens største genteknologiske institut beliggende i Shenzhen i Kina. ${ }^{5}$ Hvis jeg skal pege på et enkelt videnskabeligt samarbejde mellem Danmark og Kina, som har båret frugt, må det være dette.

Mens taksonomien udvikledes under indflydelse af især genetikken, gik redaktørerne af HBW selv i retning af at tilslutte sig et artsbegreb udviklet af Tobias et al. (2010). Her tildeles biometriske, stemmemæssige, dragtmæssige, økologiske og udbredelsesmæssige forskelle point. Hvis en potentiel art scorer i alt 7 point, regnes den for en selvstændig art, som formodes at have en høj grad af reproduktiv isolation. Molekylære data giver ikke point, men tages i betragtning i udredningen af artstatus. Omkring 9 procent af alle fuglearter har hybridiseret med andre arter, men hybridisering ændrer ikke nødvendigvis en arts udseende eller genom (del Hoyo \& Collar 2014:33). Hvis to fugleformer hybridiserer langs en 
snæver kontaktzone, tildeles de 3 point, idet dette tages til indtægt for, at de som helhed formår at opretholde deres særegenhed. Hvis to taxahybridiserer over en zone på over $200 \mathrm{~km}$, får de kun scoren 1, men det er stadigvæk mere end det nul, som mange intuitivt ville tilskrive dem. Tobias' system udmærker sig ved at definere en middelvej mellem det biologiske og det fylogenetiske artsbegreb. Alligevel har „Tobiaskriterierne“ ikke vundet generelt indpas. Fremdriften ligger i studier af genomet og dets evolution, efter at fuglene for alvor diversificerede for små 66 millioner år siden (Zhang et al. 2014; Feng et al. 2020).

På verdensplan er der nu fire forskellige lister over alverdens fugle. Tilsammen opregner de 11.524 arter (heraf 11.362 nulevende), men de er kun enige om 9.968 af dem. De fire lister er: BirdLife/HBWs med 11.126 arter; International Ornithological Committee listen (IOC listen) med 10.896 arter; Clements liste, som blev oprettet af James Clements og nu føres videre af Cornell Lab of Ornithology med 10.585 arter; og endelig Howard and Moore-listen, som er den mest konservative liste med 10.175 arter (Chukar 2019). Skønt BirdLife/HBWslisten undgik en konsekvent brug af det fylogenetiske artsbegreb, er denne liste alligevel blevet længst. Howard og Moore-listen er kortest, men den er ifølge Fjeldså (2015:5) progressiv, idet den er mere åben for molekylærbiologisk viden. I fremtiden vil forskellen mellem listerne udjævnes, hvilket er i tråd med de standardiseringsbestræbelser, som al taksonomi i stigende grad underlægges. I 2017 argumenterede Garnett og Christidis i tidsskriftet Nature for at øge regulering og gennemsigtighed i taksonomisk arbejde helt generelt. De mente, at den almennyttige organisation The International Union of Biological Sciences, ,skulle udstikke regler for inddeling af arter og overvåge taksonomien globalt" (Lottrup 2020; Garnett \& Christidis 2017). Forslaget blev mødt med anklager om stalinisme, men på et møde i februar 2020 blev der tilsyneladende opnået enighed om, hvordan taksonomien kan standardiseres uden at miste sin faglighed og uden at underlægge sig ,en eller anden komité“ (Lottrup 2020; Garnett et al. 2020).

Lande som Danmark og Sverige har deres egne komiteer, som tager stilling til fund af sjældne fugle. Dansk Ornitologisk Forenings Sjældenhedsudvalg (SU i daglig tale) følger IOC's liste. Det samme gør Norge, Finland og Storbritannien. I Sverige er der regionale sjældenhedskomiteer, som kan sende sager videre til Raritetskommittén (RK), som kvalitetssikrer fund af sjældne fugle i Sverige. Sideløbende hermed udarbejder Taxonomikommittén (TK) den officielle svenske liste over arterne i Vestpalæarktis samt tager stilling til fuglenavne. Trods deres meget begrænsede økonomi samarbejder sjældenhedskomiteer i Norden og i Europa ${ }^{6}$ Nogle komiteer er mere velrenommerede end andre. British Ornithologists' Union Records Committee vejer nok tungest, men intet afholder danske eller svenske sjældenhedsudvalg fra at træffe de afgørelser, som de mener er de rigtige. 
Uagtet hvad de nationale komiteer måtte beslutte, beholder indflydelsesrige forfattere en egen diskursiv magt. Lars Svensson, som er hædersdoktor fra Uppsala Universitet, er en af disse. Som forfatter til flere standardværker står det ham frit for at forfine sin taksonomi, som andre kan acceptere eller forkaste (Shirihai \& Svensson 2018). Den danske forfatter Klaus Malling Olsen vælger i sin bog om verdens måger at forholde sig afmålt til taksonomiske spørgsmål. Som rundet af feltfolket tilstræber han pædagogisk og pragmatisk at fremhæve de kendetegn, som er brugbare i felten, uden at udfordre mågernes taksonomi, som stadig ikke er fuldt udredt (Olsen 2018). ${ }^{7}$

Howell og Zufelt lægger i deres guide til verdens havfugle yderligere afstand til taksonomer: „... som frie feltornitologer, der ikke er havnet i den taksonomiske suppedas, som taksonomer har skabt for sig selv, vil vi anerkende biologisk diversitet uden hensyn til 'officiel' taksonomisk status". De går så langt som til at håne ,... laboratorieornitologer, som ikke vil kunne genkende den art, som de studerer, hvis de skulle finde den i toiletkummen ..." (Howell \& Zufelt 2019:344, mine oversættelser). Forfatterne bruger deres felterfaringer til at opsplitte en række havfugle og skærper dermed kravene til ligesindede feltornitologer. Disse nye arter kan måske skelnes på ynglepladserne eller fra et skibsdæk på tæt hold. Mange havfugle ses imidlertid på flere kilometers afstand over et stormomsust hav og ender alligevel med at blive artsbestemt, selv om dette strengt taget er umuligt (Christensen 2020). Sådan er de faktiske forhold inden for havobs-industrien.

\section{Twitching: efteråret 2019 i Danmark og Sverige}

Groft sagt er der to måder for en artsjæger at ,få flere arter“. Man kan enten rejse ud eller gøre sig umage hjemme. Disse to strategier er kun delvis kompatible. Ude lærer man fugle at kende, som man efterfølgende lettere kan identificere hjemme, men samtidig kan der være store omkostninger ved at forlade Skandinavien i højsæsonen. Bertil Svensson er som nævnt Sveriges toplister, men han er ikke særlig aktiv uden for Sverige. Omvendt er Claes-Göran Cederlund med sine 9.684 arter allerøverst på verdenslisten ifølge flere hjemmesider, mens han på sverigeslisten ligger langt nede. ${ }^{8}$ De to artsjægere har forskellig strategi. Man kan ikke gøre begge dele lige godt (Johansson 2014).

Når flere ,rykker“ på en melding om en sjælden fugl, kalder svenskerne det et „drag“. Folk, som sjældent misser en chance for at se en sjælden fugl, kan siges at udvise stor „,dragskicklighet“, det vil sige høj udnyttelsesgrad af krydsmuligheder. Dette begreb kan operationaliseres. En håndfuld nulevende svenske twitchere vil med stor sandsynlighed passere 500-grænsen. Enkelte vil med 50 procents 
sandsynlighed nå helt op på omkring 550 svenske arter, inden de dør. Prognosen er baseret på, at der hvert år tilføjes to-fire nye arter på sverigeslisten (Karlsson \& Wahl 2019). Den svenske Club300 blev startet i 1984. Forudsætningen for medlemskab var, at man havde krydset over 300 arter på sin liste, hvilket var sjældent dengang (Skog 2018:51). Jeg selv har i 2020 passeret min art nummer 300 på min svenske liste, hvilket placerede mig som nummer 1.598. Udviklingen inden for artsjagten har i høj grad været et plussumsspil.

Når feltfolket rykker, knyttes aktørerne i netværket - fuglene og feltfolket sammen i en event, som kan nærme sig en kunstnerisk kommunikativ performance i symfonisk samklang, eller ende i et uskønt virvar af ulovligt parkerede biler og stakåndede twitchere på jagt efter en afkræftet fugl på afveje. På årligt tilbagevendende træf sætter fuglefolket hinanden stævne i et større område, som de derefter udforsker på egen hånd. Sådanne træf er ofte rammen om markante events. De følgende afsnit startende med Blåstjerteventen er skrevet, så de har karakter af rapporter fra sådanne events.

I Danmark og Sverige er træktiderne de bedste årstider for at finde sjældenheder. Ikke mindst i maj og begyndelsen af juni forsøger feltbisserne at finde fugle, som andre efterfølgende kan rykke på. Efteråret definerer måske i endnu højere grad året som helhed (Bonser 2020). Efterårstrækket indledes allerede omkring sankthans, og sjældne fugle dukker op i hele perioden frem mod efterårsferien i uge 42, som regnes for den bedste uge. I 2019 havde Dansk Ornitologisk Forenings feltudvalg annonceret felttræf i området omkring Blåvand. For mit eget vedkommende havde jeg valgt at blive i København i håbet om, at der ville dukke en sjældenhed op i Østdanmark.

\section{Blåstjert: klassisk observation}

Jeg var derfor på Amager den 12. oktober, da Christian Glahder fandt en Blåstjert (hun eller ungfugl) i sit nærområde Allerød i Nordsjælland. ${ }^{9}$ Fuglen er sjælden, ikke mindst på en sjællandsk indlandslokalitet. Da jeg nåede frem, havde nyheden tiltrukket en håndfuld hitjægere. Det var dog først, da Carl Christian Tofte - iført indendørs futter - ufortrødent gennemsøgte kantbevoksningen omkring et moseområde, at fuglen blev genfundet. Tofte er en af de bedst kendte nordiske fuglemalere (Tofte 2015). ${ }^{10}$ Fuglen viste sig glimtvis igen, men på trods af kollektiv overvågning - og på trods af at jeg var blevet opereret for grå stær og derfor bedre kunne se - fik jeg ikke øje på den.

Dette gentog sig dagen efter, hvor jeg missede tre chancer for at se fuglen og i stedet fik et kraftigt elektrisk stød af det hegn, som omgav den kreaturfold, hvor fuglen var. Den 14. oktober så jeg endelig fuglen, efter Jørgen Munck havde 
meldt ,alt set på max. 10 m“ på meldetjenesten birdalarm.com. At „se alt“ vil her sige, at han havde set efter og mentalt registreret alle relevante feltkendetegn på en ung Blåstjert. En Blåstjert er en eftertragtet, karismatisk fugl på grund af sit udseende, specielt hannens iriserende blå overside, de rigt orangerøde flanker farvet som blommen i æg fra fritgående høns, og fordi den yngler svært tilgængeligt højt mod nord i Sibiriens og Skandinaviens sagnomspundne skove (Hayward 2016:24).

Der blev ikke rejst tvivl om artsbestemmelsen af fuglen. Dog viderebragte den allestedsnærværende Michael Køie Poulsen den oplysning, at nogle autoriteter har opsplittet Blåstjert og nu regner Himalayablåstjert (Tarsiger rufilatus) som en god art adskilt fra ,vores“ Blåstjert (Tarsiger cyanurus). Ungfuglene er nok umulige at skelne i felten. Teoretisk set kunne fuglen i Allerød derfor være en Himalayablåstjert, selv om denne art normalt er en korttrækker. Dette problem fik lov at ligge, og vi fik på klassisk vis og med ren samvittighed set en god art. Efterfølgende blev fundet godkendt af SU.

\section{Lille Rørsanger: korrektion i felten og ved fotogranskning}

Samme dag, som jeg så Blåstjerten, indløb nyheden om en Lille Gulbug i Blåvand. Den blev fundet af Thomas Bundgaard Rasmussen i et stærkt team med Ole Zoltan Göller og Michael Mosebo Jensen i moseområdet nær Blåvand Fyr. Bundgaard Rasmussen så en lys fugl, som gav ham associationer til Asiatisk Ørkensanger, men halen var for kort, og bestemmelsen blev hurtigt korrigeret til Lille Gulbug (personlig kommunikation, 18. oktober 2019). Lars Grøn - sine ret få år i felten til trods - var dog ikke overbevist, og da Rune Sø Neergaard så fotos af fuglen, ombestemtes den til Lille Rørsanger. I Dofbasen.dk skrev Lars Grøn om denne kollektive korrigeringsproces: „Mange så en Lille Gulbug. Jeg såede tvivl om arten allerede ved udmeldingen og rådførte mig blandt andet ved RSN [Rune Sø Neergaard] som omgående huggede til med Lille Rørs. Resten er historie nu:)“. En af finderne, Ole Zoltan Göller, beskriver forløbet på en måde, som vægter fotografiets rolle:

Først bestemt til Lille Gulbug og set af 70 mennesker. Drønede rundt fra busk til busk uden at vise sig godt. Virkede overvejende bleg sandfarvet uden skyggen af varmt $\mathrm{i}$ felten, hvorfor det overraskede meget at de få gode fotos der blev taget af den af MMJ [Michael Mosebo Jensen], viste en klar Lille Rørsanger med tydelig varm overgump og også ansigtskarakterer som Lille Rørs. Spøjs oplevelse (Ole Zoltan Göller, Dofbasen.dk, 14. oktober 2019). ${ }^{11}$ 
Som Lundquist bemærker:

Kameran både förlänger seendet, uppfattar sådant som det mänskliga ögat inte kan upptäcka och bidrar till ett utökat minne (Lundquist 2018:115).

Fotografier er eksempler på ,hållbara mobiler“", som oversætter det portrætterede til et digitalt sprog, som kan flyttes uden at forandres (op.cit.12).

\section{Hvidskægget Sanger og Sibirisk Bynkefugl: bestemmelse baseret på DNA}

Da jeg selv ankom til Blåvand den 16. oktober, var den Lille Rørsanger forsvundet. Den 17. oktober kørte jeg med Birthe Karpfen og Peter Hartoft-Jacobsen, som jeg tidligere havde rejst sammen med i Israel, til Mandø efter en Hvidskægget Sanger og en Sibirisk Bynkefugl. I tilfældet Blåstjert blev forvekslingsmuligheder med Blåstjert fra Himalaya udelukket. Det samme var ikke tilfældet med Hvidskægget Sanger, hvor flere former forventes at kunne dukke op i Danmark. Hartoft-Jacobsen havde allerede set en østlig form og håbede, at fuglen på Mandø ville vise sig at være vestlig form, men hunner og ungfugle er næsten ens morfologisk og også, hvad angår kald. På et foredrag under træffet afslørede SUmedlemmet Andreas Bruun Kristensen, at SU var ved at gennemgå samtlige 71 danske fund af Hvidskægget Sanger. Dette arbejde, som forelå i januar 2021, kan forventes at give genlyd internationalt herunder også i Sverige, hvor man har splittet Hvidskægget Sanger op i tre arter baseret på studier af ikke mindst Lars Svensson. ${ }^{12}$ Vidensfeltet er åbent for inputs, og taksonomiske ændringer institutionaliseres decentralt selv inden for de nordiske lande (Nielsen et al. 2021). Angående fuglen på Mandø kom der 29. september 2020 meddelelse om, at DNAanalyse havde vist, at det var den vestlige form, nu benævnt Iberisk Sanger, og ikke en af de to andre taxa.

Situationen angående Sibirisk Bynkefugl ligner problematikken om Hvidskægget Sanger. I både Danmark og Sverige er arten opsplittet i Sibirisk Bynkefugl (Saxicola maurus) og Stejnegers Bynkefugl (Saxicola stejnegeri), men fuglen på Mandø var svær at placere artsmæssigt, selv om den lod sig iagttage i et åbent område. Derfor blev der også i dette tilfælde indsamlet ekskrementprøver med henblik på artsbestemmelse via DNA-analyse, nu ofte benævnt „pølle-birding“. Artsjægerne måtte sætte fundet ,i banken“, hvor det stod i et år, før fuglen blev DNA-bestemt til Sibirisk Bynkefugl. 


\section{Østlig Lundsanger: ny art for landet reddet på falderebet}

Den 18. oktober foreslog Peter Hartoft-Jacobsen en tur til Tipmosen, hvor Michael Mosebo Jensen lige havde meldt en Hvidbrynet Løvsanger. Vi mødte flere andre i området, og det lykkedes os at finde hele to Hvidbrynede Løvsangere. Andreas Egelund Christensen og Claus Brostrøm Nielsen påpegede imidlertid igen og igen, at der var ,noget galt" med den ene, men de fik hverken set eller hørt fuglen særlig godt. Peter og jeg så fuglen i fint medlys, og en forbipasserende fugleinteresseret fik nogle gode fotos. Mistanken i gruppen rettede sig mod en mulig Himalayasanger, som er en svagere farvet udgave af Hvidbrynet Løvsanger. Som indiensinteresseret kender jeg denne art alene af den grund, at den tidligere hed Humes Sanger og var opkaldt efter medstifteren af Indiens Kongresparti. Jeg var sikker på, at fuglen i Tipmosen var for grøn i dragten til at være en Humes. Jeg tænkte imidlertid ikke ud af boksen og hen i retning af Østlig Lundsanger, selv om jeg havde set denne art i Kina få måneder forinden. Jeg var ikke i stand til at trække på min egen ,avian knowledge“ om større områder, som jeg ellers har foreholdt alle at gøre (Madsen 2018:399). Jeg fik heller ikke fotografen til at vise sine fotos til Andreas Egelund Christensen og Claus Brostrøm Nielsen. Det var en alvorlig undladelsessynd. Havde disse skarpe yngre folk set disse fotos, kunne fuglen være blevet bestemt på kortere tid. Fuglen skulle være blevet talt op, ikke bare lidt, men meget.

Aftenen blev tilbragt med at fejre træffets afslutning. Prisen for træffets bedste fugl tilfaldt Thomas Bundgaard Rasmussen for fundet af den Lille Rørsanger, men sent på aftenen blev Mosebo Jensen kontaktet af Rasmus Strack og Andreas Bruun Kristensen. Ud fra Mosebos ret dårlige fotos, som de havde set på dofbasen.dk, luftede de tanken om, at dagens fund kunne dreje sig om intet mindre end en Østlig Lundsanger. Denne art var blevet splittet fra Lundsanger for nogle år siden. Næste morgen tog flere af de, som havde kommunikeret aftenen og natten før, tilbage til åstedet for at tjekke fuglen og om muligt ,redde brøleren“. De fandt fuglen, som snart blev endeligt bestemt til Østlig Lundsanger (Haaning 2019; Olsen \& Jensen 2020). Peter Hartoft-Jacobsen og jeg kunne selv have bidraget afgørende til identifikationen af fuglen, men Andreas Egelund Christensen og Claus Brostrøm Nielsen var utvivlsomt tættere på at knække koden. I en kommentar til et indlæg på Facebook-gruppen Feltornitologen den 19. oktober medgav Andreas Egelund Christensen sin utilstrækkelighed med ordene: „OK. Jeg tror vi har smidt noget dyrt væk“ og en vred smiley. I felten sagde han: „Jeg er ikke voksen nok til at lave en NFL.“" En NFL er en ,ny for landet", underforstået en ny art for landet. Men hvem kan siges at have fundet, eller ædlet, fuglen, når der er tale om et samarbejde, hvor folk i felten „nudges“ af andre i et lynpeerreview. 
Netfugls regler specificerer, at ,[S]elvom finderen af arten ikke selv formår at bestemme fuglen korrekt, er det kun finderen, som har ret til at krydse arten som ædelart". I overensstemmelse hermed har Mosebo Jensen lagt fundet ind på netfugl.dk som ædlet af ham selv. ${ }^{13}$ Samtidig anerkender han, at ikke-tilstedeværende ,skrivebordsgendarmer" $i$ to tilfælde under træffet havde korrigeret bestemmelsen af arter, som han havde fundet eller været med til at finde. Mosebo Jensen konkluderer at:

Skal der uddrages nogen lære af hele denne affære, så må det helt klart være, at jeg vist skal lære at kommunikere bedre med mit kamera. Når jeg nu har taget billeder, kan jeg jo lige så godt kigge ordentligt på dem ... (Jensen 2019).

Felttræffets arrangører var enige. Thomas Böhmer skrev: ,[S]lev (sic) om fuglen indenfor træfperioden blev efterbestemt ud fra billeder, blev træffets sjældneste fugl den Østlige Lundsanger (ny art for landet) og præmien tildeles Michael Mosebo for dette hårde fund." Thomas Bundgaard Rasmussen måtte derfor aflevere det trofæ, som han havde fået. Han kommenterede selv dette på feltudvalgets Facebook-side med et ordvalg hentet fra sportens verden: „Jeg vil gerne takke feltudvalget for at lade mig smage sejrens sødme fra fredag kl. 15 til lørdag morgen kl. 8, hvor VAR-kendelsen blev konfirmeret.“ Ikke desto mindre skrev Rasmus Strack således på samme Facebook-side om Mosebos hårde fund: „Hårde fund? I kan bare sende præmien for den Østlige Lundsanger til mig. “

Hvis et foto hurtigt spredes, får flere folk mulighed for at byde ind og sikre identifikationen. Som under en jagt koordineres arbejdsindsatsen. I løbet af et felttræf strejfer folk rundt i området i forsøg på at lokalisere en sjældenhed, men når et bytte lokaliseres, samles jægerne. Autoritetsstrukturen under jagten er acephal. Der er konkurrence om at lokalisere et hit, men også samarbejde om at bestemme det. Byttet tilskrives den enkelte finder, som kan tilføje det på sin ædelartsliste, men det deles ligeligt, idet alle observatører kan afkrydse arten. Eftersom selv dygtige feltornitologer er afhængige af, at andre finder sjældne fugle, fremmes et bredt samarbejde. Enkelte feltbisser forsøger at finde alt selv. Dette gælder Danmarks mest effektive finder af sjældne fugle, Sebastian Klein, som derved fremstår som gavegiveren, der kun lejlighedsvis modtager andres gaver (Klein 2021).

\section{Tajgafluesnapper: telefonisk tilskyndelse}

For anden gang nogensinde afholdtes i januar 2020 the Danish Birder Award Show. ${ }^{14}$ Showet er modelleret over en Hollywood-skabelon. I alt 15 priser blev uddelt som belønning for indsatsen i fugleåret 2019. Ingen fik prisen for fundet 
af Østlig Lundsanger. Prisen for Årets Guldfugl gik i stedet til Frank Desting for fundet af endnu en ny art for landet, nemlig en Tajgafluesnapper. Fuglen blev fundet i Gentofte Folkepark den 10. november og set frem til skumringen af et stort antal mennesker. Der blev i argumentationen for pristildelingen lagt vægt på, at fundet blev gjort på en indlandslokalitet af Desting alene, men rent faktisk modtog også han hjælp til bestemmelsen fra andre. Det var igen SU-medlemmet Andreas Bruun Kristensen, som iværksatte den nudgingproces, som førte til, at andre mødte op og kunne fotodokumentere fundet (Kristensen 2020). Barren for, hvornår der er tale om ædling, kan altid diskuteres. I Norge er der folk, som mener, at hvis man bruger nogen som helst form for hjælpemidler, inklusive felthåndbøger, så er der ikke tale om ædling:

Den edle følelse skal komme fra hjarterota. Du SKAL ha en god følelse for krysset. Du SKAL være overvist om at du har claimet rett art, og MESTRET bestemmelsessituasjonen (Hundeide 2013:260).

I en lille historie om en Gråsejler, som han egenhændigt fandt og bestemte i Skåne, men som blev forkastet af RK, indtil der forelå gode fotos, skriver Carl Christian Tofte: „Det er ikke dem der bliver ringet op, som ædler. Det her er min fugl“ (Tofte 2018:8). Ja, ædle ædlere ædler alene, men mindre ædle ædlere bliver ringet op. Det bør tilføjes, at Desting helt på egen hånd også fandt og bestemte en Gråsejler i 2019.

\section{Sverige: klassiske observationer}

For fuglefolket i Sverige bød efteråret 2019 ligeledes på situationer, hvor behovet for klare krydsregler ikke blev indfriet. Dog kom der som i Allerød også i Sydsverige smukke fugle nordfra, som kunne nydes uden klassifikatoriske kvaler. Det var ikke Blåstjert, men et stort antal krognæb. Mange af disse „tallbit“, som de hedder på svensk, lod sig iagttage helt tæt på. Jeg så arten den 2. november på en ekskursion med en forening, som hedder Gjuserna afledt af „fiskgjuse“, det vil sige fiskeørn. Ekskursionen gav fire „gjusekryss“" på foreningens kollektive liste, hvilket, som det fremgår af turlederens rapport, blev behørigt fejret:

Då det blivit nya gjusekryss denna dag avslutade vi med ett besök på Knut Jöns konditori i Båstad för att fira dette. Kaffe och allhelgonabakelse avnjöts. Vid genomgang av artlistan visade det sig att det blivit inte mindre än fyra nya kryss, nämligen tallbit, alkekung, vattenpiplärka och toppskarv. Flera av dagens deltagare fik även ett antal livskryss. Det är kul att vara exkursionsledare när det bliver en sådan lyckad exkursion. Totalt blev det 59 arter (Nilsson 2019). 


\section{Østlig Gul Vipstjert: taksonomisk udfordring}

To dage senere blev der meldt Østlig Gul Vipstjert også benævnt Motacilla flava tschutschensis eller Motacilla tschutschensis, alt eftersom man opfatter den som en underart eller som en selvstændig art. Det er velkendt, at Gul Vipstjert har mange former. I 1960-udgaven af Europas fugle bemærkes tørt:

Obs.: De Gule Vipstjerters systematik er indviklet ... de bastarderer, hvor deres yngleområder mødes. Under almindelige iagttagelser i naturen er det i reglen formålstjentligt at kalde alle for 'Gule Vipstjerter' (Peterson et al. 1960:280).

Nogle autoriteter, inklusive Lars Svensson, er stadig utilbøjelige til at opsplitte Gul Vipstjert, men blandt andet en artikel i Dutch Birding (Bot et al. 2014) har udredt komplekset på en måde, som gør splits mere meningsfulde. Det er i hvert fald tydeligt, at Østlig Gul Vipstjert stadig oftere registreres rundt om i Europa (Birdguides 2020). Dagens fugl befandt sig på stranden nær Halmstad på Hallands kyst. På gerningsstedet var opmærksomheden rettet ikke blot mod fuglens udseende, men dens kald: Var det „rasping“, som den hollandske artikel foreskrev? Var kaldet „raspigt“? Mere „rivigt“? Mere „vass“" end almindelig Gul Vipstjerts? Min hørelse er for dårlig til at opfatte disse kald, men nogle hårdskådare kan høre forskel, og de belagde også begivenheden med lydoptagelser.

Under sit feltarbejde fik Elin Lundquist adgang til et møde i RK. På dette møde behandledes tidligere fund af unge Gule Vipstjerter:

I dagsläget bedömer Rk att det krävs dna och/eller lätesinspelningar för att kunna föra unga gulärlor med grå dräkt till ras eller rasgrupp. Kommittén tar fortsatt gärna emot rapporter som grå gulärlor, och uppmanar observatörer att försöka fånga läten på inspelning och att samla in tappade fjädrar eller avföring (Lundquist 2018:155).

For fuglen i Halland og for en anden fugl, som senere dukkede op i Skåne, er disse krav nu opfyldt, men udredningen kompliceres af, at disse vipstjerters cellekerneDNA kan pege i én retning, mens deres mitokondrie-DNA kan pege i en anden (Maclean et al. 2005). Uklarhed såvel udseendemæssigt som stemmemæssigt og genetisk vil gøre det svært for Raritetskommittén at godkende fundet som en ny art for Sverige. Indtil da må svenske kryssare sætte dette kryds i banken, hvor det kan stå og afvente en taksonomisk afgørelse, der kan bringe det til udbetaling.

\section{Azurmejse: art eller hybrid?}

Bedst som jeg iagttog den Østlige Gule Vipstjert på Hallandskysten, kom der „larm“ fra birdalarm.com i form af en notifikation om en Azurmejse øst for Kiruna 
tæt på den svensk-finske grænse. Temperaturen i området var 25 minusgrader, og en tur derop ville koste i omegnen af 5.000 SEK med fly til Kiruna og videre i lejet bil til byen, hvor en lokal fugleinteresseret lovede gratis overnatning. Fuglen forblev på stedet nogle dage, men det blev ret hurtigt klart, at langtfra alle svenske hårdskådare var indstillet på at rykke på mejsen, selv om flere mangler den på deres sverigesliste. Azurmejsen er mere eftertragtet end Blåstjert, men er dog ikke på niveau med rubinnattergalen, som både i Sverige, Danmark og i Norge (Hundeide 2013:255, note 149) har status som en „drømmefugl“, som alle formodes at ville se.

Tilbageholdenheden skyldtes, at Azurmejsen i manges øjne er blevet en „sur mejse", fordi to tilsyneladende gode fund efterfølgende er blevet underkendt af RK. Sidst skete dette med en mejse på Öland i oktober 2016. Under en østenvindsperiode fandt der en legendarisk tilstrømning sted af fugle fra det fjerne Østen, herunder Sibirisk Jernspurv, Sibirisk Rørspurv, og hvad der lignede en smuk Azurmejse. Lundquist:

Dagen efter att Azurmesen hade upptäckts var hundratals fågelskådare på plats på morgonen. När jag var där tillsammans med min pappa var det en annan skådare som utbrast: 'Fy fan vad fin den är! Varför är det ingen som skriker?! Och inga träd är det i vägen heller' (Fältanteckningar 2016-10-14, Lundquist 2018:87).

Orgiastiske reaktioner på at se en sjældenhed er ikke uvanlige. Hundeides beskrivelse af situationen, da en alpesejler passerede lige hen over en gruppe i Falsterbo, er rammende:

'HELVETE SÅ GODT!' skrikes det, 'Satan så godt!' Utropet gjentas minst seks ganger av en høy kar i 35-årsalderen med caps og Leica-kikkert. Fyren går ned i knestående idet han uttrykker sin ekstatiske glede, stemmen er på bristepunktet mens han nok en gang skriker 'faen så godt!' og ser intenst rett opp med sin eksklusive kikkert (Hundeide 2013:242).

Situationen på Öland var anderledes, idet Azurmejsen forblev på samme plads $\mathrm{i}$ længere tid. Under sådanne omstændigheder har folk sikkert prioriteret studiet og dokumentationen af fuglen frem for fejring af observationen.

Der er ingen tvivl om, at Azurmejse er nært beslægtet med Blåmejse, og at de to arter hybridiserer mellem Hviderusland og Uralbjergene. Blandingsformen har været kendt som Pleske's Tit i over 100 ĺr (Ůawicki 2012:219). Fuglen på Öland lignede en Azurmejse langt mere end en Blåmejse. Spørgsmålet var, om der var nogle træk, som tydede på hybridisering. Her faldt Ölands-fuglen på for lidt hvidt $i$ halen og dækfjerene og en for skarp vinkel i det hvide på den mellemste af tertiærerne. ${ }^{15}$ Som det fremgår af RK's egen artikel om beslutningen, er forskel- 
lene minimale (Raritetskommittén 2019). RK tillod simpelthen meget lidt variation inden for arten Azurmejse, før der blev dømt hybridisering. RK's holdning virkede så meget desto strengere, fordi den finske sjældenhedskomité var mere large med, hvor megen variation der skulle være tilladt for en Azurmejse. På denne baggrund var hitjægerne tilbageholdne. En af dem udtrykte sin holdning til en tur til Lapland for at se, hvad der måske var en hybrid - en „blazurmes“ med disse ord: ,Jag åker inte på annat än säkra azurmesar.“16

Blazurmejseaffæren udmøntede sig i en protestaktion, hvor den svenske Club300 samlede penge ind til et større studie af Azurmejsens genom. Målet var sat til 75.000 SEK, og indsamlingen foregik både på Bird Fair i Falsterbo og via internettet, hvor man blev opfordret til at støtte projektet, for eksempel på Black Friday. Tilsyneladende forventer Club300, at genetikken kan lede til en afklaring, men genetikken er et tveægget sværd, som ikke nødvendigvis løser artsjægernes problemer. Alligevel lever håbet om, at et grundigt genetisk studie kan lede til, at de to forkastede fund bliver godkendt. Hvorfor skulle en Azurmejse ikke kunne være en Azurmejse selv med et lille indslag af Blåmejse, spurgte Roadrunners kritiske kronikør Mattias Larsson (Larsson 2019). Mikael Nord, som er kendt for sit arbejde på Naturum Getterön nær Varberg, istemte kravet om mere forbrugervenlige taksonomiske modeller og opfordrede Club300 (C3) til selv at tage skridtet: „RK gör ju ett fantastiskt jobb men C3 skulle utan problem kunna

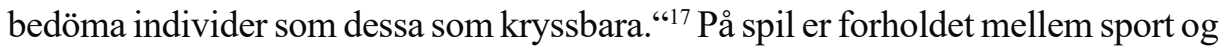
videnskab. Mikael Nords forslag vil betyde, at fuglefolket tager et skridt væk fra den videnskabelige tilgang, hvor ,[E]nligt Club300:s kryssregler får alltså endast fynd som godkänts av kommittén räknas" (Lundquist 2018:158). Et skridt i retning af en mere forbrugervenlig taksonomi er som at klippe den navlestreng over, som forbinder twitchere med ornitologien. Muligheden for i højere grad at udøve, hvad videnskabssociologen Steve Fuller (2016) kalder „epistemisk demokrati“, er tillokkende. Samtidig står det klart, at Club300 tøvede med at undsige sig taksonomiens taktstok. I stedet for at advokere for en særskilt feltornitologisk krydsliste valgte Club300 at sponsorere en artsudredning via genetikken.

\section{Konklusion og perspektivering}

De beskrevne events, som repræsenterer nogle af de feltornitologiske højdepunkter i efteråret 2019, lader skinne igennem, hvilke bestemmelsesmæssige og taksonomiske udfordringer er mest aktuelle, nemlig de fotografiske og de genetiske. I konklusionen vil jeg perspektivere dette set i lyset af udviklingen inden for kunstig intelligens og postmodernistisk identitetspolitik. 
Kikkert og teleskop er stadig feltfolkets standardudrustning, men som det fremgår af eksemplerne, har digitale kameraer delvis flyttet fokus fra at beskrive en fugl i ord til at bestemme den via fotos. I 2019 hændte det for første gang, at en ny art for landet utilsigtet blev dokumenteret, da en fuglefotograf i Skagen opdagede, at han havde taget et billede af en spansk spurv uden at ane det (Christiansen \& Olsen 2020). Digitale kameraers receptionshistorie er en feltornitologisk succeshistorie. Mine eksempler viser, at digitale kameraers integration i feltfolkets og skrivebordsgeneralernes praksis har hævet kompetenceniveauet, men på bekostning af begrebet ,at ædle“. Udviklingen er langtfra afsluttet. I 2019 lanceredes en digital kikkert med indbygget kamera, som via en app på ens mobiltelefon kan bestemme fugle. Kikkerten er udviklet af smykke- og kikkertproducenten Swarovski og Cornell Lab of Ornithology. Ifølge Hart og Kelling (2020) vil kunstig intelligens allerede i 2025 favne mange af de kompetencer, som feltfolket nu besidder. For eksempel vil en ,smart feeder“ kunne sende besked til ens mobiltelefon om, at den har lokaliseret og verificeret en sjælden fugl på ens foderbræt. Vil digitale løsninger aflære færdigheder, og vil en sådan ,de-skilling“ (Lundquist 2018:193) påvirke incitamentsstrukturen, når ekspertise indlejres i kameraer, databaser, robotter og andre ,artsorakler“ snarere end i feltornitologernes hjerner og kroppe? Mennesker kan genkende fugle. Fugle kan genkende fugle. Snart kan Golem genkende både mennesker og fugle. Hobbyornitologer, som ikke er skolet på de måder, som Kuhn, Law og Lynch beskrev, vil blive hjulpet af digitale genkendelsesteknologier, som samtidig vil kunne bemyndiges til at frasortere bevidst fejlbehæftet og opdigtet information sat i omløb af såkaldte „stringers“ (Franzen et al. 2021; Berggren 2019). Golem vil kunne optræde som lærer, politi og dommer - feltornitologernes glansroller.

Den mest akutte udfordring anno 2019 var den molekylærbiologiske, hvor en ny slags fagfolk, laboratorieornitologerne, stadig oftere blev inddraget. Indtil videre er det feltornitologerne selv, som indsamler det biologiske materiale og sender det til velrenommerede laboratorieornitologer. Analysen tager tid, og resultatet kan af uindviede opfattes som et partitur med noder, som man ikke er i stand til at læse, men som alligevel har status af en endegyldig fatwa.

Laboratorieornitologerne selv er ofte mere ydmyge. Ligesom feltbestemmelse er krævende, er analyse af arvemateriale svær og fejlbehæftet. Betænk blot, hvordan entusiastiske forskere ved Nationalt Center for Miljø og Energi i 2015 på graverende vis overestimerede ulvebestanden i Danmark. ${ }^{18}$ Selv valide data er ikke nødvendigvis entydige (MacLean et al. 2005:522). Det er ikke alle fænotypiske træk, som afspejles i arvemassen, og det er ikke alt i arvemassen, som iklædes kød og blod. Fænotype og genotype er ikke brofaste. Ifølge taksonomer som Per Alström er vejen frem en integreret afvejning af udseende, stemme, 
adfærd, udbredelse og arvemasse (Alström 2014, 2015). Min formodning er, at feltornitologerne fremover vil finde, at dette er en fair deal. Feltornitologer er villige til at udviske skellet mellem amatør og professionel og skellet mellem sport og videnskab, men som historien om Azurmejsen viser, nøler Club300 i Sverige med at tilsidesætte den orden, som taksonomien skaber. Feltfolkets søgen efter essentielle feltkendetegn, deres konsekvente artsfiksering, deres viden og erfaring og deres nidkære gensidige kontrol og overvågning cementerer en tilgang, som gør konkurrence baseret på rimeligt klare regler mulig. Disse regler er bundet op på en videnskabelig taksonomisk orden, som for sit vedkommende drives frem af molekylærbiologiske landvindinger.

Siden 1970'erne har videnskaben mistet meget af sin autoritet. Ifølge Harry Collins bør videnskabsmanden ses som ,en ærlig håndværker, der ud fra ædle motiver gør sit bedste, men som uundgåeligt laver fejl“" (Collins et al. 2020:76, min oversættelse). I stedet anlægges ofte et postmodernistisk perspektiv, der ser videnskab som et udtryk for hvide mænds strukturelle vold. Sat på spidsen går det identitetspolitiske projekt ud på at dekonstruere oplysningstidens hegemoniske diskurs og erstatte denne vestlige arvesynd med en essensliggjort, uanfægtelig, politisk korrekt diskurs (Collins et al. 2020; Libak 2020; Pluckrose \& Lindsay 2020; Sokal 2006).

Denne drejning har især fundet sted i USA og i Storbritannien. Netop her ser mange mennesker på fugle. I 2020 ledte det under Black Lives Matter-bølgen til, at flere ornitologiske foreninger omskrev deres historie og ændrede deres ledelsesform, at racisme i felten blev tematiseret, og at fuglenavne blev revideret i politisk korrekt retning (Brune 2020; Waters 2020; Elbein 2020). I Sverige fjernede TK allerede i 2015 navnet „kafferseglar". „Kafir" er det arabiske ord for en vantro, som ikke anerkender profeten Muhammeds lære, men ændringen blev foretaget, fordi ordet er blevet brugt nedladende af hvide om indfødte i Sydafrika. Bortset fra denne ændring i nomenklaturen er postmodernistisk identitetspolitik ikke slået igennem i svensk og dansk ornitologi endnu, men i tråd med at fagdisciplinære koryfæer er centrale mål for de identitetspolitiske renselsesbestræbelser, er Carl von Linné blevet anklaget for at være den videnskabelige racismes ophavsmand. I Sverige og Norge er der blevet rejst krav om at fjerne Linné fra det offentlige rum og omskrive historien om ham (SVT 2020; Charmantier 2021; Frangsmyr 1988; Shah 2020).

Vil denne debat påvirke feltornitologien? Sikkert, men feltornitologerne vil næppe acceptere, at videnskab først og fremmest skulle være et spørgsmål om diskursiv magt. Ifølge videnskabsfilosoffen Karl Popper er gode teorier lig med vovede teorier, som sætter meget på spil, men som samtidig kan falsificeres (Popper 2012:248). De fleste feltornitologer føler sig forpligtet til at annoncere 
deres fund af sjældenheder, selv om det kan være forbundet med prestigetab at fejlbestemme sjældenheder. I felten, på meldesystemerne, i databaserne og i andre fora øges troværdighed gennem kvalitetssikring, hvor der nådesløst frasorteres, forkastes og falsificeres. Ledetråden i feltornitologien er at: „... här lämnas inte en enda fågel obestämd, sanningen måste fram, allt ska artas!“ (Halldén 2019:18). Ikke mange videnskabelige fora kan mobilisere gatekeepers eller skrivebordsgendarmer, som i en sen aftentime kan foretage et peerreview, der i sværhedsgrad svarer til at ombestemme en Hvidbrynet Løvsanger til en Østlig Lundsanger. Kravet om nøje observation, korrekt bestemmelse og taksonomisk orden gør feltornitologien mindre kompatibel med postmodernismen selv set i lyset af, at kunstig intelligens og laboratorieornitologi indsnævrer feltornitologiens domæne.

\section{Noter}

1. Begrebet „serious hobby“ blev udviklet af R.A. Stebbing i 1982 (Lee et al. 2015). Se også Roux et al. (2009) om ,cognitive passion“.

2. Se https://myriadbirds.com/resources/references/og https://www.bookscrolling.com/the-bestbooks-about-or-featuring-birds/.

3. Jeg vil takke Frank Abrahamsen, Gunnar Broberg, Florian Charvolin, Jan Hjort Christensen, Carsten Enevoldsen, Thyge Enevoldsen, Kim Frost, Michael Harbsmeier, Peter Hartoft-Jacobsen, Michael Hundeide, Michael Mosebo Jensen, Sakari Kauppinen, Kristine Vik Kleffel, Erik Kramshøj, Shyamal Lakshminarayan, Jens Lind, Michael Lynch, Prathibha Holloway Madsen, Martin Junker Nielsen, Klaus Malling Olsen, Michael Køie Poulsen, Dhruv Raina, Cecilie Rubow, Steven Sampson og afdøde Uffe Gjøl Sørensen for på forskellig vis at have bidraget til denne artikel.

4. Strack (2018 med opdateringer) er et forsøg på at sammenstille de to lister i et mere retvisende „klassement" baseret på både åben information og insider-viden. Netfugl.dk er ved at blive flyttet til beta.netfugl.dk/.

5. https://en.genomics.cn/.

6. Se henholdsvis https://birdlife.se/rk/, https://birdlife.se/tk/og https://enacademic.com/dic.nsf/ enwiki/2347995.

7. I et mere vidtgående indlæg 4. januar 2021 på Feltornitologens Facebook-side foreslår Malling Olsen at oprette en decideret „feltornitologisk krydsliste“, se www.facebook.com/groups/ 222495431241303/user/651979040/.

8. http://www.surfbirds.com/cgi-bin/surfbirds/display.cgi?highVal=49\&list=list1 og https: //igoterra.com/rankings?group=33\&rank=8\&area=312025\&year=-1\&observedSeen=1 .

9. https://dofbasen.dk/popobs.php?obs=obs\&obsid=23439912.

10. Toftes tegning af Blåstjerten kan ses på https://dofbasen.dk/popobs.php?obs=obs\&obsid=234 41854. 
11. Se https://dofbasen.dk/popobs.php?obs=obs\&obsid=23560255 og https://dofbasen.dk/popobs .php?obs=obs\&obsid=23454541; det tidlige foto på https://service.dofbasen.dk/media/image/ o/23454541_20191014103731_961473254.png; og et senere foto på http://club300.dk/photo s.php?ua=show\&id $=1286$.

12. https://club300.se/svenska-faagellistan/svenska-faagellistan/roedstrupig-saangare-sylvia-cantillans-eastern-subalpine-warbler/.

13. http://netfugl.dk/ranking.php?id=xregler og http://netfugl.dk/ranking.php?id=various\&mode $=$ list_chronological\&ranking_id=3\&profile_id $=106$.

14. https://pandion.dof.dk/artikel/danish-birder-awards.

15. Tertiærerne er de tre fjer på fuglens vinge, der sidder inden for armsvingfjerene, nærmest kroppen.

16. Jörgen Agerskov, 5. november 2019, Vår Fågelvärld Facebook-side, https://www.facebook.com/ groups/var.skadarvarld.

17. Mikael Nords svar til Anders Lindström, 11. november 2019, Vår Fågelvärld Facebook-side, https://www.facebook.com/groups/var.skadarvarld.

18. ulvetracking.dk/der-er-formentlig-kun-faa-ulve-i-danmark-vurderer-forskere/.

\section{Litteratur}

Alström, Per

2014 Ordning i klassen! Taxonomi och systematik. Exempel från fåglarnas värld. Del

1. Fauna och Flora 109(4):28-41. https://www.slu.se/globalassets/ew/subw/artd/

5-om-artdatabanken/personal/per-alstrom/6.-publications/popular-science-paper/ alstrom-2014-2015-fageltaxonomi-del-1-2-fauna-o-flora.pdf. Læst 27.2.2021.

2015

Ordning i klassen! Taxonomi och systematik. Exempel från fåglarnas värld. Del 2. Fauna och Flora 110(1):2-16. https://www.slu.se/globalassets/ew/subw/artd/5-omartdatabanken/personal/per-alstrom/6.-publications/popular-science-paper/alstrom2014-2015-fageltaxonomi-del-1-2-fauna-o-flora.pdf. Læst 27.2.2021.

Berggren, Bengt

$2019 \quad$ Stringare. En kort betraktelse. Roadrunner 101(1):46-49.

Birkhead, Tim, Jo Wimpenny \& Bob Montgomerie

2014 Ten Thousand Birds. Ornithology since Darwin. Princeton \& Oxford: Princeton University Press.

Birdguides

2020 Review of the Week. 18.-31. december. https://www.birdguides.com/articles/ review-of-the-week-18-31-december/. Læst 27.2.2021.

Bonser, Richard

2020 Twitching in Britain and Ireland. Indlæg på Danish Star Birder Award Show. 25. januar.

Bot, Sander, Dick Groenendijk \& H. Herman van Oosten

2014 Eastern Yellow Wagtails in Europe. Identification and Vocalisations. Dutch Birding 36:295-311. 
Brune, Michael

2020 Pulling Down our Monuments. 22. juli, Sierra Club. www.sierraclub.org/michaelbrune/2020/07/john-muir-early-history-sierra-club. Læst 27.2.2021.

Charmantier, Isabelle

2021 Linnaeus and Race. Linnean Society of London. www.linnean.org/learning/whowas-linnaeus/linnaeus-and-race. Læst 27.2.2021.

Christensen, Jan Hjort

2020 Anmeldelse af Howell og Zufelt (2019). Dansk Ornitologisk Forenings Tidsskrift 114(1):23-24.

Christiansen, Simon S. \& Kent Olsen

2020 Første fund af spansk spurv (Passer hispaniolensis) i Danmark. I: P. Lange (red.): Fugleåret 2019. Side 178-79. København: Dansk Ornitologisk Forening.

Chukar

2019 The Four Different Checklists of Birds of the World. Santa Monica Bay Audobon Society, baseret på Eran Tomer, "Avian Taxonomies Compared". 9. marts. https: //smbasblog.com/2019/03/09/the-four-different-checklists-of-birds-of-the-world/. Læst 27.2.2021.

Collins, Harry

2013 Three Dimensions of Expertise. Phenomenology and the Cognitive Sciences 12: 253-73. DOI 10.1007/s11097-011-9203-5.

Collins, Harry, Robert Evans, Darrin Durant \& Martin Weinel (eds)

2020 Experts and the Will of the People. Society, Populism and Science. Cham: Palgrave Pivot.

Elbein, Asher

2020 The Bird World is Grappling With Its Own Confederate Relic. McCown's Longspur. Audubon Magazine, 2. juli. www.audubon.org/news/-bird-worldgrappling-its-own-confederate-relic-mccowns-longspur. Læst 27.2. 2021.

Feng, Shaohong, Josefin Stiller, Yuan Deng et al.

2020 Dense Sampling of Bird Biodiversity Increases Power of Comparative Genomics. Nature 587:252-57. https://doi.org/10.1038/s41586-020-2873-9.

Fjeldså, Jon

2013 Ny klassifikation af verdens fugle. Dansk Ornitologisk Forenings Tidsskrift 107(3):222-24.

2015 Fuglenes systematik og en ny DOF-navneliste. Dansk Ornitologisk Forenings Tidsskrift 109(1):3-6.

2020 Fuglenes evolution. Et nyt perspektiv. 20. oktober. YouTube. https://

www.youtube.com/watch?v=XrwDs7R8p_4\&t=2105s. Læst 27.2.2021.

Frangsmyr, Tore (ed.)

1988 [1983] Linnaeus. The Man and His Work. Dehra Dun: Bishen Singh Mahendra Pal Singh.

Franzen, Martina, Laure Kloetzer, Marisa Ponti, Jakub Trojan \& Julián Vicens

2021 Machine Learning in Citizen Science. Promises and Implications. In: K. Vohland, A. Land-Zandstra, L. Ceccaroni, R. Lemmens, J. Perelló, M. Ponti, R. Samson $\&$ K. Wagenknecht (eds): The Science of Citizen Science. Pp. 183-98. Cham: Springer. https://doi.org/10.1007/978-3-030-58278-4_10. 
Fuller, Steve

2016 Embrace the Inner Fox. Post-Truth as the STS Symmetry Principle Universalized. 25. december. Social Epistemology Review and Reply Collective. http://wp.me/ p1Bfg0-3nx.

Garnett, Stephen T. et al.

2020 Principles for Creating a Single Authoritative List of the World's Species. PLOS Biology 18(7):1-10. https://doi.org/10.1371/journal.pbio.3000736.

Garnett, Stephen T. \& Les Christidis

2017 Taxonomy Anarchy Hampers Conservation. Nature 546:25-27. doi:10.1038/ $546025 \mathrm{a}$.

Gjerris, Mickey \& Cecilie Rubow (red.)

2018 Naturens sprog. Historier fra virkeligheden om fortryllelse. Frederiksberg:

Eksistensen.

Halldén, Erik

2019 Tredje Gråhuvade Sparven. Roadrunner 4:18-19.

Hansen, Morten D.D.

2018 Vi, som inhalerede. I: M. Gjerris \& C. Rubow (red.): Naturens sprog. Historier fra virkeligheden om fortryllelse. Side 28-35. Frederiksberg: Eksistensen.

Hart, Peter \& Steve Kelling, Jessie Barry, Brian Sullivan \& Chris Wood

2020 Birding With Technology in the Year 2025. Our Predictions. The Cornell Lab. 9. januar. https://www.allaboutbirds.org/news/birding-with-technology-in-the-year2025-our-predictions/. Læst 27.2.2021.

Hayward, Neil

2016 Lost Among the Birds. Accidentally Finding Myself in One Very Big Year.

New York: Bloomsbury.

Hodkinson, Trevor R. \& John A.N. Parnell

2019 Introduction to the Systematics of Species Rich Groups. In: T.R. Hodkinson \& J.A.N. Parnell (eds): Reconstructing the Tree of Life. Taxonomy and Systematics of Species Rich Taxa. Pp. 3-20. Boca Raton: CRC Press.

Howell, Steve N.G. \& Kirk Zufelt

2019 Oceanic Birds of the World. A Photo Guide. Princeton \& Oxford: Princeton University Press.

Hoyo, Joisep del \& Nigel J. Collar

2014 Illustrated Checklist of the Birds of the World. HBW \& BirdLife International. Vol. 1. Non-Passerines. Barcelona: Lynx.

Hundeide, Michael T.

2013 Ornitologisk praksis som persepsjon av naturen. Om naturopplevelse, kunnskapservervelse og naturhistorisk entusiasme. Socialantropologisk institutt, Series of dissertations submitted to the Faculty of Social Sciences 420.

Oslo: University of Oslo.

Haaning, Henrik

2019 Østlig lundsanger. Haaning i felten. 21. oktober. https://pandion.dof.dk/artikel/ $\% \mathrm{C} 3 \% \mathrm{~B} 8$ stlig-lundsanger. 
Jensen, Michael Mosebo

2019 Hvad kameraet fortalte. En finderberetning om fundet af Østlig Lundsanger, Phylloscopus plumbeitarsus. 20. oktober. http://www.netfugl.dk/ news.php?id=show\&news_id=7105dacc3994dc6d; også offentliggjort på https:

Johansson, Roland //www.club300.dk/articles.php?ua=show\&id=511. Læst 27.2.2021.

2014 Svensk fågelskådare i världstopp. Hallands Nyheter, 19. maj. https://www.hn.se/ nyheter/varberg/svensk-f\%C3\%A5gelsk $\% \mathrm{C} 3 \% \mathrm{~A} 5$ dare-i-v\% $\% 3 \% \mathrm{~A} 4$ rldstopp1.2177256. Læst 27.2.2021.

Karlsson, Måns \& Felix Wahl

2019 Roadrunner kollar vem som får största Sverigeslistan. Roadrunner 2:44-47.

Kastner, Joseph

1986 A World of Watchers. New York: Alfred A. Knopf.

Klein, Sebastian

2021 Den store stygge statistik III. 1. januar. https://beta.netfugl.dk/artikler/1967/ forsoeg. Læst 27.2.2021.

Kristensen, Andreas Bruun

2020 Taigafluesnapperen ved Gentofte Sø. Club300.dk. 22. januar. http://club300.dk/ articles.php?ua=show\&id=513. Læst: 27. februar, 2021.

Kuhn, Thomas S.

1977 The Essential Tension. Selected Studies in Scientific Tradition and Change. Chicago \& London: University of Chicago Press.

Larsson, Matias

2019 RK \& Mesarna. Roadrunner 1:66.

Law, John \& Michael Lynch

1990 [1988] Lists, Field Guides, and the Descriptive Organization of Seeing. Birdwatching as Exemplary Observational Activity. In: M. Lynch \& S. Woolgar (eds):

Representation in Scientific Practice. Pp. 267-99. Cambridge, MA: MIT Press.

Ławicki, Łukasz

2012 Azure Tits and Hybrids Azure x European Blue Tit in Europe. Dutch Birding 34: 219-31.

Lee, Sunwoo, Kelly McMahan \& David Scott

2015 The Gendered Nature of Serious Birdwatching. Human Dimensions of Wildlife 20:47-64. https://doi.org/10.1080/10871209.2015.956375.

Libak, Anna

2020 Skyldig til det modsatte aldrig bliver bevist. København: Kristeligt Dagblads Forlag.

Liep, John

1996

Luftbåren kula. Danske feltornitologers tilegnelse af fugle. Tidsskriftet

Antropologi 33:5-19.

2001 Airborne Kula. The Appropriation of Birds by Danish Ornithologists.

Anthropology Today 17(5):10-15. https://doi.org/10.1111/1467-8322.00077.

Lindroth, Sten

1988 [1983] The Two Faces of Linnaeus. In: T. Frangsmyr (ed.): Linnaeus. The Man and His Work. Pp. 1-62. Dehra Dun: Bishen Singh Mahendra Pal Singh. 
Lottrup, Kristoffer

2020 Artsproblemet. Weekendavisen, 31. juli, Ideer:4-5.

Lundquist, Elin

2018 Flyktiga möten. Fågelskådning, epistemisk gemenskap och icke-mänsklig karisma. FD avhandling, Institutionen för etnologi, religionshistoria och genusvetenskap.

Stockholm: Stockholms Universitet.

Maclean, Norman, Martin Collinson \& Richard G. Newell

2005 Taxonomy for Birders. A Beginners' Guide to DNA and Species Problems. British Birds 98:512-37.

Madsen, Stig Toft

2018 Asian Studies in the Nordic Region. Status, Relevance, Prospects. Vestnik of Saint Petersburg University. Asian and African Studies 10(3):392-404. https://doi.org/ 10.21638/spbu13.2018.308.

Mitchell, Andrew

2018 Tracing Wolves. Materiality, Effect and Difference. Dissertation. Stockholm: Department of Social Anthropology, Stockholm University.

Mynott, Jeremy

2009 Birdscapes. Birds in Our Imagination and Experience. Princeton \& Oxford: Princeton University Press.

Nielsen, Henrik Haaning, Andreas Bruun Kristensen, Simon Sigaard Christiansen \& Sakari Kauppinen

2021 Hvidskægget sanger-komplekset er blevet mere komplekst. Genbehandling af fund i Danmark. 30. januar. https://beta.netfugl.dk/artikler/2015/hvidskaegget-sangerkomplekset-er-blevet-mere-komplekst. Læst 27.2.2021.

Nilsson, Lars-Olof

2019 Bjärehalvön 2/11 och fyra nya Gjusekryss. Ringsjöbygdens Fågekskådare. www.gjuse.se/bjarehalvon-2-11-och-fyra-nya-gjusekryss/. Læst 27.2.2021.

Olsen, Kent \& Michel Mosebo Jensen

2020 Østlig lundsanger (Phylloscopus plumbeitarsus) - ny art for Danmark. I: P. Lange (red.): Fugleåret 2019. Side 183-85. København: Dansk Ornitologisk Forening.

Olsen, Klaus Malling

2018 Gulls of the World. A Photographic Guide. Princeton: Princeton University Press.

Peterson, Roger Tory, Guy R. Mountfort \& P.A.D. Hollom

1960 Europas fugle. På dansk ved Bernt Løppenthin, Holger Poulsen \& Finn

Salomonsen. København: Gads Forlag.

Pluckrose, Helen \& James Lindsay

$2020 \quad$ Cynical Theories. Great Britain: Swift Press.

Popper, Karl

2012 [1963] Science as Falsification. In: M. Lynch (ed.): Science and Technology Studies II. Pp. 245-51. London \& New York: Routledge.

Raritetskommittén

2019 Så greppar RK hybriderna. Vår Fågelvärld 1:34-41. https://bit.ly/2pLsDYz. 
Roux, Jacques, Florian Charvolin \& Aurélie Dumain

2009 "Cognitive Passions" or the Rebellious Dimension of Knowledge in the Passion Scheme. Revue d'Anthropologie des connaissances 3(3):a-p. https:// www.cairn.info/revue-anthropologie-des-connaissances-2009-3-page-a.htm. https: //doi.org/10.3917/rac.008.0001.

Samuelson, Per

2006 Ser du tärnen i det blå? En studie av föreställningar om galenskap inom Club 300. D-uppsats, Socialantropologi. Lund: Lunds Universitet.

Shah, Sonia

2020 The Next Great Migration. London: Bloomsbury Publishing.

Shirihai, Hadoram \& Lars Svensson

2018 Handbook of Western Palearctic Birds, Passerines. Sydney: Helm.

Skog, Susanne Nylund

2018 Samlare, jägare och andra fågelskådare. Stockholm: Carlssons i samarbete med Instituttet for språk och folkminnen.

Sokal, Alan D.

2006 Pseudoscience and Post-Modernism. Antagonists or Fellow-Travelers? In: G. Fagan (ed.): Archeological Fantasies. Pp. 286-361. London: Routledge.

Strack, Rasmus

2018 DK-klassementet. Club300.dk. http://club300.dk/articles.php?ua=show\&id=457\#2 765. Læst 27.2.2021.

SVT

2020 Statyprotesterna når Sverige. Namnlista mot Linné. 24. juli. www.svt.se/kultur/ carl-von-linne.

Tobias, Joseph, Nathalie Seddon, Claire Spottiswoode, John Pilgrim, Lincoln Fishpool \& Nigel Collar

2010 Quantitative Criteria for Species Delimitation. Ibis 154(4):724-46. https://doi.org/ 10.1111/j.1474-919X.2010.01051.x.

Tofte, Carl Christian

2015 Ørneflugt. Kunsten at se på rovfugle. Hillerød: Koustrup.

2018 Historien om en gråsejler. I: P. Lange (red.): Fugleåret 2018. Side 6-9. København: Dansk Ornitologisk Forening.

Waters, Hannah

2020 What White Birders Can Learn From Amy Cooper About Their Own Racism.

Audubon Magazine, 2. juli. www.audubon.org/news/what-white-birders-can-learnamy-cooper-about-their-own-racism.

Zhang, Guojie, Cai Li, Qiye Li et al.

2014 Comparative Genomics Reveals Insights into Avian Genome Evolution and Adaptation. Science 346(6215):1311-20. DOI: 10.1126/science.1251385. 